\title{
Luiz CARLos Nogueira: O TeSTEMUNho dE UM COMPROMISSO ÉTICO COM A PSICANÁLISE
}

\author{
Christian Ingo Lenz Dunker
}

\begin{abstract}
Conheci Luiz Carlos em 1988, na disciplina Linguagem e Psicanálise, que depois se desdobrou em uma série de grupos de estudo, cartéis, módulos da antiga Biblioteca Freudiana, bem como em um conjunto de congressos, eventos e atividades associativas dos quais destaco a antiga Associação Psicanalítica Escrita Freudiana e o atual Fórum do Campo Lacaniano. Nestes quinze anos estive às voltas com a tentativa de decifrar seu estilo e, sem dúvida, com os efeitos de seu ensino. Digo decifrar porque seu ensino parece atravessado por uma série de tramas e de exigências que no momento em que se consegue pegar uma delas é como se os outros fios da meada ... a gente não soubesse o que fazer com eles. Acho que só mais tarde compreendi que isso tinha que ver com a sua tese maior, ou seja, a irredutibilidade do inconsciente e da experiência analítica.
\end{abstract}

Antes disso, Luiz Carlos parecia-me sobretudo um kantiano. Ou seja, alguém que via a psicanálise atravessado pela experiência da crítica. Da crítica aos fundamentos da psicanálise na realidade objetivável e no mundo sensível da percepção. A ênfase na linguagem ocuparia, assim, o lugar da razão como campo do sujeito. Era pelo kantismo que me parecia compreensível seu forte diálogo com a universidade. Ressalte-se, a universidade, aqui, era problema e não solução. Problema tanto do ponto de vista formativo quanto do ponto de vista da reunião de saberes com fundamentos distintos, sinteticamente a filosofia e a ciência. Aqui, dois textos marcaram nossas discussões: Lacan e a Filosofia de Alain Juranville e A Obra Clara de Jean Claude Milner, além, é claro, de o Lacan de A Ciência e a Verdade. Disso resultava um Lacan que recolocava a Psicanálise em diálogo com a ciência, 
ao mesmo tempo em que subvertia seu sujeito. Na outra face, a filosofia de Heidegger e Hegel que era chamada, com muita propriedade, e de preferência sem preciosismos, para entendermos que o saber em questão na psicanálise era de outra natureza. Nisso éramos jogados de um lado para o outro a espera de que, em algum momento, a síntese salvadora viria. Claro que não vinha. Enquanto isso, cultivávamos o mito do Lacan unificador dos saberes e ganhávamos, em contrapeso, noites insones, dedicadas aos clássicos da epistemologia ocidental.

Resolvido que a psicanálise não era nem a ciência rediviva nem a chave da filosofia feita por um anti-filósofo, mas estabelecido que, se não se podia chegar a esta conclusão sem a dura tentativa que a precede, chegamos a um outro terreno onde a solução parecia se adiantar: a ética. Nos tempos do mais puro terror institucional estava lá Luiz Carlos, fazendo nos ver que tudo, ou quase tudo, estava no Seminário 7. As mais vetustas demonstrações cabalistas, em torno de uma lógica política movida a palavras de ordem, eram defletidas com a ética e, o principal, eticamente. Mais uma vez Kant, agora o da Razão Prática, aparecia no horizonte. Neste momento agudo, onde teria sido fácil levantar objeções e catalisar uma posição alternativa, em vez de respostas, o que encontrávamos eram problemas. $\mathrm{O}$ caráter radicalmente não objetivável do sujeito era lembrado sempre que se impunha uma solução genérica. A ética como questão, escansão, aporia e não como agir automático em nome de uma causa. Abismávamos ao ouvir coisas como "Sim, você tem razão, mas esta foi a solução que Lacan encontrou, qual é a sua solução?". Aquele que muitas vezes era, injustamente, acusado de repetir Lacan, mantinha uma cuidadosa distância da autoridade da qual poderia se utilizar, atento que era a seus efeitos alienantes. A ênfase na ética ficava, assim, curiosamente limitada pela lembrança de que se tratava da experiência analítica e não de visão de mundo. Mas essa ênfase na ética combinava com um efeito que só se podia extrair em ato no seu ensino. Era uma lição de humildade intelectual e de horror à soberba que assola às praias lacanianas.

Neste ponto, começamos a ouvir mais e mais sobre esta experiência singular que é a clínica psicanalítica. Toneladas de conceitos e as mais in- 
Luiz Carlos Nogueira: O Testemunho de um Compromisso Ético com...

trincadas exigências formativas dobravam seu peso diante da força da simplicidade. É o momento da Tese de Livre Docência A Psicanálise: Uma Experiência Original - O Tempo de Lacan e a Nova Ciência. Nela está registrado o grande debate com a ciência e a filosofia, nela aparece a ética sempre em seu lugar estratégico, mas, além disso, junta-se o fio do próprio tratamento analítico. A pesquisa de cada um sobre o inconsciente. O exercício, que ele gostava de comparar à prática do piano, mas também com o encontro criativo comparável ao fazer artístico. A dimensão não antecipável da relação entre falantes sob transferência. $\mathrm{O}$ ato primordial tomado em seu tempo e sob seu lugar. Aqui aparecem temas malditos na tradição lacaniana. Esta experiência original é transformadora, cria algo novo e artificial. Ela deve se orientar pela autonomia, constituindo uma nova forma de construção, que não pode ser comparada a nenhuma outra já inventada pelo lomem. A Tese dá continuidade à vertente de crítica do objeto, agora no plano do objeto do fantasma, no objeto de gozo e no objeto como negatividade. A crítica do objeto como referente e ao saber como totalidade juntam-se, assim, sob a égide da noção de experiência: abordada agora fora da apreensão intuitiva e imediata como um real problema. A lição que vinha junto com esta volta de seu ensino era, mais uma vez, o retorno à força simplificadora do simbólico, em sua simplicidade, mas também de um certo humor surpresivo, que não estávamos acostumados a reconhecer no professor.

Tratava-se de uma lição antecipatória. Isso colocava em cena o problema não evidente das condições sob as quais se poderia falar da experiência analítica. É pelo veio epistêmico e não pelo político, ou da garantia, que a questão do passe se colocava. Severas e acaloradas foram as discussões neste ponto. Avesso à polêmica como método e às soluções práticas como exigência de ocasião, Luiz Carlos nos convidava sempre à exigência do pensamento. Retorno aos textos, portanto, e à Proposição em primeiro lugar. Rapidamente, constatamos as disparidades entre suas versões, o que, somado com os relatos históricos e testemunhos, gerava um quadro de caos e incerteza. Lição de método: nestes casos, antes de dois passos à frente, um à trás. Voltemos a falar sobre este tal estabelecido consenso: o significante e a linguagem. $\mathrm{O}$ mundo caindo e nós, aqui, no movimento da linguagem ao 
significante e do significante à linguagem. Sim ... o passe - precisamos falar mais sobre isso.

Parece que nesta volta algo que estava lá, desde o início, de repente surgia como novo: a Lógica. Desde as primeiras aulas, Luiz Carlos não escondia sua predileção sobre o artigo sobre o Tempo Lógico. Parecia o complemento natural da série: o significante, a linguagem ... e o tempo lógico. A lógica, à qual nos acostumáramos a ver como uma continuidade do estruturalismo lacaniano parecia dar frutos para além dos ganhos em termos de transmissão e rigor. Agora a coisa era incontornável. Os fios se juntavam novamente. A crucialidade do Seminário 11, que nos ocupara por tanto tempo, não residia apenas na importância do objeto $a$, nem na afirmação do inconsciente como algo ético cernido por uma estrutura temporal, mas na inovação metodológica, sem a qual não se podia entender a diferença entre alienação e separação, bem como as conjecturas em torno do Real. Além disso, ficava nítida a linha de força que unia o Seminário 11 ao Seminário 16, o gozo como categoria logicamente apreensível.

Não chegamos a um acordo sobre se o recurso aos matemas prescinde da linguagem natural e se isso é, portanto, condição suficiente e necessária para falar da experiência analítica. Posso dizer, no entanto, que tudo o que escrevi, até hoje, sobre psicanálise, incluindo minha tese, da qual Luiz Carlos fez uma brilhante argüição, está marcado por este diálogo. Minha tese é sobre o tempo, sem dúvida alertado por ele para a crucialidade deste tema na obra de Lacan. Meu primeiro livro, sobre a interpretação, responde à sua insistência na linguagem, em sua dimensão tensa entre ética e lógica. Meu livro sobre o gozo está atravessado por esta espécie de chamado de retorno à clínica, que dele ouvi.

Em Psicanálise, às vezes parece feio dizer que se tem um mestre, ainda bem que pude ter o meu. Obrigado. 